\title{
Selection of Entomopathogenic Nematodes to Control Nymphs of Haplaxius crudus (Van Duzee) (Hemiptera: Cixiidae)
}

\author{
Miriam Rosero Guerrero ${ }^{1}$, Alex Enrique Bustillo Pardey ${ }^{2}$ \\ ${ }^{1}$ Colombian Oil Palm Research Center, Paratebueno, Colombia \\ ${ }^{2}$ Colombian Oil Palm Research Center, Bogotá, Colombia
}

Email address:

mrosero acenipalma.org (M. R. Guerrero), abustillo acenipalma.org (A. E. B. Pardey)

\section{To cite this article:}

Miriam Rosero Guerrero, Alex Enrique Bustillo Pardey. Selection of Entomopathogenic Nematodes to Control Nymphs of Haplaxius crudus (Van Duzee) (Hemiptera: Cixiidae). American Journal of Entomology. Vol. 3, No. 1, 2019, pp. 24-29. doi: 10.11648/j.aje.20190301.14

Received: January 29, 2019; Accepted: March 20, 2019; Published: May 15, 2019

\begin{abstract}
Haplaxius crudus transmits the pathogen that causes Lethal wilt (ML for its name in Spanish), one of the main diseases that affects oil palms in Colombia. In its nymphal stage it feeds from grasses present at the plantations, and adults feed on oil palm leaves. With the objective of controlling the nymphal stage of $H$. crudus, the effectiveness of the following entomopathogenic nematodes was assessed: Steinernema colombiense, S. websteri, Steinernema sp. 1, Steinernema sp. 2, Heterorhabditis bacteriophora, Heterorhabditis sp. (Gua 31), Heterorhabditis sp. (Gua 236), Heterorhabditis sp. (CPHsp1301) and Heterorhabditis sp. (CPHsp1302). Pathogenicity was assessed under laboratory conditions using Petri dishes with roots of Paspalum virgatum. Virulence was assessed using mesh houses with PVC tubes and plastic trays with $P$. virgatum. Once the most virulent nematode was selected, three dosage levels were assessed under simulated field conditions, in order to select the most effective dosage. All assessed nematode species were pathogenic to nymphs of $H$. crudus, and nymph stage IV was the most susceptible stage, with death rates of over $80 \%$. Regarding virulence, there were statistically significant differences among treatments $(\mathrm{P} \leq 0.05)$, producing nematode death rates between 28.3 and 88.2\%. Heterorhabditis sp. (CPHsp1301), obtained from the soil of palm plantations, was selected because it caused a mortality rate of $78.4 \%$ with at a dosage of 1300 $\mathrm{IJ} / \mathrm{cm}^{2}$ in the sprayed area. The results are promising and further research should be performed under commercial oil palm plantation conditions.
\end{abstract}

Keywords: Oil Palm, Biological Control, Steinernema, Heterorhabditis

\section{Introduction}

Lethal wilt (ML for its name in Spanish), is one of the main diseases that affects oil palms (Elaeis guineensis Jacq.) in Colombia. It was recorded for the first time in the eastern region of the country in 1994, in the Bajo Upía area [1] and has forced the eradication of 670,562 palms between 2010 and 2017 in the Colombian eastern palm growing region [2].

The vector insect of the agent that causes ML is Haplaxius crudus (Van Duzee, 1907) (Hemiptera: Cixiidae) [3]. The nymphs of $H$. crudus grow in the roots of grasses located at superficial levels of the soil, often in decomposing fallen leaves at a depth of $3 \mathrm{~cm}$. In the adult stage they feed on the leaves of different types of palms by inserting their stylet into the tissue of the leaf to suck the phloem [4-7], which implies that the adult stage is the only stage that is considered a vector for ML.

Infected palms display necrosis of the tips of the bracts of immature blossoms, the fruits are easily detached from the bunches and the leaflets begin to dry out from the tip to the base, causing the edges to roll in. This symptom is usually preceded by a yellow strip that becomes more diffused as the disease advances [7-8].

Numerous natural enemies of $H$. crudus have been reported in Mexico and USA (Florida), such as spiders, mites, hymenopterans and the entomopathogenic fungus Hirsutella citriformis [6, 9-12]. In Colombia, Cenipalma has been able to isolate in oil palm plantations $H$. crudus adults infected by Metarhizium anisopliae. Oil palm plantations attempt to control this insect by means of periodic application of insecticides, with a low success rate, while 
incurring in higher production costs and affecting beneficial fauna in the plantations. The control measures for lethal wilt recommended by Cenipalma are to perform early detection of the disease, eradicate the affected palms, monitor adult $H$. crudus with yellow sticky traps, and eradicate grasses and sedges at plantations, replacing them for wide-leaf foliage [7, 13].

Because the nymphs of $H$. crudus are found in the roots of grasses and sedges in the ground of oil palm plantations [5], entomopathogenic nematodes are considered a viable control alternative. The entomopathogenic nematodes of the Steinernematidae and Heterorhabditidae families are considered important biological controllers for insects with in-soil reproductive habits $[14,15]$. They display important features such as high virulence, the capacity to move about to search for, find and infect insects and the ability to survive for long periods of time in the soil with no host. They are also harmless to the environment and mammals and compatible with other entomopathogenic species [16-21].

Based on the above, the objective of this study was to assess the effectiveness of the entomopathogenic nematode species in controlling nymphs of $H$. crudus.

\section{Materials and Methods}

\subsection{Location}

The study was carried out in laboratory conditions $(25 \pm$ $3{ }^{\circ} \mathrm{C}$ and $\left.63 \pm 13 \% \mathrm{RH}\right)$, and in a mesh house (26.76 \pm $3.56{ }^{\circ} \mathrm{C}$ and $\left.78.77 \pm 13.79 \% \mathrm{RH}\right)$ at the facilities of Cenipalma in Villanueva, Casanare and at the plantations of the Experimental Field Palmar de las Corocoras, in Paratebueno, Cundinamarca $\left(26.2{ }^{\circ} \mathrm{C}, 73.4 \% \mathrm{RH}\right.$ and 2451 mm of rainfall).

\subsection{Biological Materials}

Nine species of entomopathogenic nematodes were used for the pathogenicity experiments (Table 1), reproduced from larvae in the last stage of Galleria mellonella L. (Lepidoptera: Pyralidae), following the procedure established in references [22, 23]. The nematodes used in all the experiments had emerged 24 hours earlier from $G$. mellonella larvae. The nymphs of $H$. crudus were obtained from the colony of Cenipalma established at the plantation of Guaicaramo S. A., in Barranca de Upía, Meta.

Table 1. Entomopathogenic nematodes assessed for control of nymphs of Haplaxius crudus.

\begin{tabular}{ll}
\hline Nematode & Origin \\
\hline Heterorhabditis bacteriophora & Fresno, Tolima \\
Heterorhabditis sp. (CPHsp1301) & Tumaco, Nariño \\
Heterorhabditis sp. (CPHsp1302) & Villanueva, Casanare \\
Heterorhabditis sp. (Gua 31) & Guática, Risaralda \\
Heterorhabditis sp. (Gua 236) & Guática, Risaralda \\
Steinernema colombiense & Quimbaya, Quindío \\
Steinernema websteri & Chinchiná, Caldas \\
Steinernema sp. 1. & Buenavista, Quindío \\
Steinernema sp. 2. & Chinchiná, Caldas \\
\hline
\end{tabular}

\subsection{Pathogenicity Experiments}

The pathogenicity of the nematodes was assessed in laboratory conditions in two experiments, the first using stage III nymphs of $H$. crudus and the second with stage IV nymphs. The experimental unit consisted of one $9 \mathrm{~cm}$ Petri dish with filter paper, in which roots of the grass Paspalum virgatum $\mathrm{L}$. were placed, and three nymphs of $H$. crudus. The nymphs used in the experiments were put in contact with 100 IJ (infective juveniles) $/ \mathrm{cm}^{2}$ of the nematodes applied by spraying, in $2 \mathrm{ml}$ of sterile water. Only sterile water was applied to the control treatment. The experiments were performed using fully random sampling with 10 treatments (nine species of entomopathogenic nematodes plus the control group) (Table 1). Each treatment had 10 repetitions for a total of 30 nymphs per treatment.

The assessments of mortality of the nymphs of $H$. crudus were performed daily over eight days. Observations were also made on the production of nematodes in $50 \%$ of the dead individuals using a modified "White" camera [24]; the remaining $50 \%$ of dead individuals were analyzed through dissection to establish the number of nematodes that had managed to become parasites of each specimen 24 hours after death. The data were analyzed using analysis of variance and the differences of treatment were assessed using the Duncan test at $5 \%$ by means of the SAS 9.3 statistical package.

\subsection{Virulence Experiments}

The virulence of the nematodes was assessed under mesh house conditions with the nematode species selected in the previous experiment that had caused a mortality rate of over $80 \%$ in the nymphs. The experiments were divided into two groups; first, an assessment was performed for the species of Steinernematidae (S. colombiense, S. websteri, Steinernema sp. 1 and Steinernema sp. 2), and afterwards of the species of Heterorhabditidae (H. bacteriophora, Heterorhabditis sp. (CPHsp1301), Heterorhabditis sp. (Gua 31) and Heterorhabditis sp. (CPHsp1302)), due to the availability of nymphs of $H$. crudus at the Breeding Unit for this insect.

The experimental unit consisted of $P$. virgatum planted in containers (tubes) of polyvinyl chloride (PVC) of $5 \mathrm{~cm}$ in diameter and $7 \mathrm{~cm}$ long infested with 10 stage IV nymphs of $H$. crudus. The nymphs were put in contact with $100 \mathrm{IJ} / \mathrm{cm}^{2}$ applied by spraying in suspension in $10 \mathrm{ml}$ of sterile water. The experiments were performed based on a fully random design with five treatments, four Heterorhabditidae species plus a control group (first experiment) and four Steinernematidae species plus a control group (second experiment). Each treatment had six repetitions. The assessments on mortality of $H$. crudus were performed every 48 hours, until the adults emerged.

Afterwards, a new experiment was conducted under simulated field conditions using the nymphs of $\mathrm{H}$. crudus. The experimental unit consisted of plastic trays, $30 \mathrm{~cm}$ long by $23 \mathrm{~cm}$ wide, planted with $P$. virgatum plants and infested with 17 stage IV nymphs. The nymphs were put in contact with $1300 \mathrm{IJ} / \mathrm{cm}^{2}$ applied by spraying in $150 \mathrm{ml}$ of sterile water. Each tray was covered with hollow cylinder made 
from wire and covered with tulle cloth. The experiments used a fully random statistical design. Each treatment had six repetitions for a total of 102 nymphs per treatment. Nymph mortality and the emergence of $H$. crudus adults were recorded every 48 hours over 15 days.

\subsection{Assessment of the Most Effective Dosage}

Once the most virulent nematodes on nymphs of $H$. crudus were selected, experiments were carried out to establish the most effective dosage for controlling the nymphs of this insect under mesh house and field conditions. The experimental unit consisted of $P$. virgatum plants planted in plastic trays, $30 \mathrm{~cm}$ long by $23 \mathrm{~cm}$ wide (area: $690 \mathrm{~cm}^{2}$ ) by 12 $\mathrm{cm}$ tall, infested with 17 nymphs of $H$. crudus. The experiment in the mesh house was performed under a fully random design, with four treatments and six repetitions. Three dosages of the selected nematodes were assessed: 100, 500 and $1300 \mathrm{IJ} / \mathrm{cm}^{2}$ of the experimental unit.

\subsection{Field Assessment}

In field conditions at an oil palm plantation, the nematode selected in the above experiment was assessed in three dosages, 500, 1000 and $1300 \mathrm{IJ} / \mathrm{cm}^{2}$ under a full random block design. The experimental unit consisted of $P$. virgatum planted in plastic trays, $30 \mathrm{~cm}$ long by $23 \mathrm{~cm}$ wide (area: $690 \mathrm{~cm}^{2}$ ) by 12 $\mathrm{cm}$ tall, infested with 17 nymphs of $H$. crudus. Each experimental unit was placed under an oil palm and covered with a cylinder formed by a wire structure covered with tulle cloth. The IJs were sprayed using a hand-held spray gun in the planned dosages. Nymph mortality and the emergence of adults of $H$. crudus were assessed every 48 hours over 15 days.

The data were analyzed by means of analysis of variance and the differences between treatments were analyzed using the Duncan test at 5\%, using the SAS 9.3 statistical package.

\section{Results and Discussion}

\subsection{Experiments of Pathogenicity}

All the assessed nematode species were pathogenic for nymphs of $H$. crudus and there were statistically significant differences in the mortality rates they produced on the assessed species (Table 2). In the laboratory, most species of entomopathogenic nematodes infect a wide variety of insects because they come into direct contact with their hosts, the environmental conditions are propitious and there are no ecological barriers to infection $[14,25]$.

It was also found that susceptibility varies depending on the insect's age: the nematodes are more pathogenic on more developed nymphs, finding that in stage IV nymphs the mortality rates were over $80 \%$, with the exception of one species, whereas in stage III mortality rates were below $57 \%$ (Table 2). Similar results were found in a study with Aeneolamia varia Fabricius (Hemiptera: Cercopidae), which also found that nematode susceptibility increases with age: stage IV nymphs were more susceptible to the nematodes [26]. Other studies found that second instars of Bradysia odoriphaga Yang \& Zhang (Diptera: Sciaridae) were less susceptible to infection by nematodes as compared with the older stages (third and fourth instar and pupae) [27]. This susceptibility may be attributed to the size of the natural cavities (mouth, anus and spiracles) that are the entry point for the entomopathogenic nematodes [28].

Table 2. Mortality (\%) of stage III and IV nymphs of Haplaxius crudus caused by entomopathogenic nematodes under laboratory conditions.

\begin{tabular}{lll}
\hline \multirow{2}{*}{ Entomopathogenic nematodes } & \multicolumn{2}{l}{$\%$ mortality nymphs of $\boldsymbol{H}$. crudus } \\
\cline { 2 - 3 } & Stage III & Stage IV \\
\hline Heterorhabditis bacteriophora & $45.2 \mathrm{a} *$ & $93.3 \mathrm{a}$ \\
Heterorhabditis sp. (CPHsp1301) & - & $90.0 \mathrm{a}$ \\
Heterorhabditis sp. (Gua 31) & $47.6 \mathrm{a}$ & $90.0 \mathrm{a}$ \\
Steinernema colombiense & $57.1 \mathrm{a}$ & $86.7 \mathrm{a}$ \\
Steinernema websteri & $50.0 \mathrm{a}$ & $93.3 \mathrm{a}$ \\
Steinernema sp. 1. & $45.2 \mathrm{a}$ & $96.7 \mathrm{a}$ \\
Steinernema sp. 2. & $45.2 \mathrm{a}$ & $100.0 \mathrm{a}$ \\
Heterorhabditis sp. (Gua 236) & - & $53.3 \mathrm{~b}$ \\
Control & $14.3 \mathrm{~b}$ & $10.0 \mathrm{c}$ \\
\hline
\end{tabular}

*Data in the same column followed by the same letter are not significantly different, according to the Duncan test $(\mathrm{P} \geq 0.05)$.

Regarding the penetration of the assessed nematodes in $H$. crudus, they managed to enter the body of the nymphs and multiplied inside it. The greatest production of IJs was found with $S$. colombiense, with an average of $4810 \mathrm{JI} /$ nymph (Table 3). The multiplication of the nematode inside the insect would not only affect the susceptible state, but the nematodes that emerge from the corpse could also cause secondary infections in other development stages and increase inoculation in the field [29]. In this regard, in the references [30, 31] mention that applications of Heterorhabditis sp. in the field on Popillia japonica Newman (Coleoptera: Scarabaeidae) and Leucopholis lepidophora Blanchard (Coleoptera: Scarabaeidae) enabled the nematode to reproduce inside the insect, to emerge and to produce secondary infections and reference.

Table 3. Average number of nematodes that parasitized and emerged in stage III and IV nymphs of Haplaxius crudus.

\begin{tabular}{|c|c|c|c|c|}
\hline \multirow{2}{*}{ Entomopathogenic nematodes } & \multicolumn{2}{|c|}{ Juveniles that parasitized } & \multicolumn{2}{|c|}{ Emerging infective juveniles } \\
\hline & Stage III & Stage IV & Stage III & Stage IV \\
\hline Heterorhabditis bacteriophora & 5.0 & 29.0 & 102.5 & 306.0 \\
\hline Heterorhabditis sp. (CPHsp1301) & - & 8.0 & - & 3697.2 \\
\hline Heterorhabditis sp. (Gua 236) & - & 7.0 & - & 725.0 \\
\hline Steinernema colombiense & 5.0 & 6.0 & 115.6 & 4810.0 \\
\hline Steinernema websteri & 15.0 & 17.0 & 152.3 & 565.2 \\
\hline Steinernema sp. 2. & 4.0 & 33.0 & 4.0 & 1311.4 \\
\hline
\end{tabular}


The symptomatology observed in the dead nymphs of $H$. crudus were flaccidity, incapability of developing on to the adult stage and reddish color in the case of the Heterorhabditidae species (Figure 1).

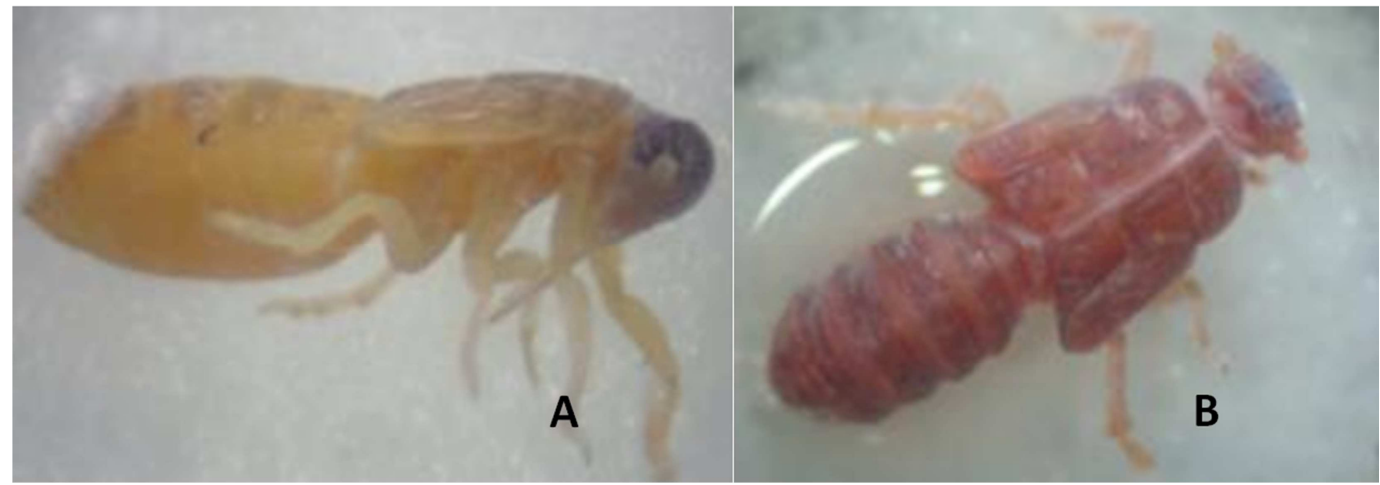

Figure 1. Symptomatology of nymphs of Haplaxius crudus infected with entomopathogenic nematodes. A. nymph infected with Steinernema sp. B. Change of color caused by Heterorhabditis sp.

\subsection{Experiments of Virulence}

The virulence experiments found that all the assessed nematode species were virulent on nymphs of $H$. crudus and there were statistically significant differences in the mortality rates they produced on the assessed species (Table 4). In the experiment with plastic trays, that were most similar to field conditions, there were statistically significant differences among the species of Heterorhabditis ( $\mathrm{F}=17.33$; $\mathrm{df}=4$; $\mathrm{P}<$ 0.0001 ) and the mortality rates were above $60 \%$. Meanwhile, the Steinernema species produced mortality rates above $80 \%$ and there were no differences among them $(\mathrm{F}=55.60 ; \mathrm{df}=4$; $\mathrm{P}<0.0001$ ) (Table 4).

The nematode species Steinernema sp1. and Heterorhabditis sp. (CPHsp1301) were the most virulent of each family and were selected for further use in the dosage assessment study, and subsequently for assessment in the field. Heterorhabditis sp. (CPHsp1301) has an additional attribute, in that it is native in isolation at an oil palm plantation in Tumaco, Nariño.

Table 4. Mortality (\%) of stage IV nymphs of Haplaxius crudus caused by entomopathogenic nematodes under mesh house conditions.

\begin{tabular}{|c|c|c|}
\hline \multirow{2}{*}{ Entomopathogenic nematodes } & \multicolumn{2}{|c|}{ \% mortality nymphs of $\boldsymbol{H}$. crudus } \\
\hline & PVC & Plastic trays \\
\hline & \multicolumn{2}{|c|}{ Experiment 1} \\
\hline Heterorhabditis bacteriophora & $36.7 \mathrm{a}^{*}$ & $71.6 \mathrm{a}$ \\
\hline Heterorhabditis sp. (CPHsp1301) & $38.3 \mathrm{a}$ & $74.5 \mathrm{a}$ \\
\hline Heterorhabditis sp. (Gua 31) & $28.3 \mathrm{a}$ & $74.5 \mathrm{a}$ \\
\hline Heterorhabditis sp. (CPHsp1302) & $60.0 \mathrm{~b}$ & $63.7 \mathrm{a}$ \\
\hline \multirow[t]{2}{*}{ Control } & $6.6 \mathrm{c}$ & $14.7 \mathrm{~b}$ \\
\hline & \multicolumn{2}{|c|}{ Experiment 2} \\
\hline Steinernema colombiense & $53.3 \mathrm{a}$ & $84.3 \mathrm{a}$ \\
\hline Steinernema websteri & $51.7 \mathrm{a}$ & $88.2 \mathrm{a}$ \\
\hline Steinernema sp. 1. & $71.7 \mathrm{~b}$ & $88.2 \mathrm{a}$ \\
\hline Steinernema sp. 2. & $70,0 \mathrm{~b}$ & $84.3 \mathrm{a}$ \\
\hline Control & $8.3 \mathrm{c}$ & $14.7 \mathrm{~b}$ \\
\hline
\end{tabular}

*Data in the same column followed by the same letter are not significantly different, according to the Duncan test $(\mathrm{P} \geq 0.05)$.

\subsection{Assessment of Dosage Effectiveness}

The assessment of dosage in the case of Steinernema sp. 1 displays statistically significant differences $(\mathrm{F}=126.96$; $\mathrm{df}=$ 4; $\mathrm{P}<0.0001)$. The dosage of $1300 \mathrm{IJ} / \mathrm{cm}^{2}$ produced the highest mortality rate of $75.4 \%$ (Table 5 ). In the second experiment to assess the dosage of Heterorhabditis sp. (CPHsp1301), there were statistically significant differences ( $\mathrm{F}=43.8 ; \mathrm{df}=3 ; \mathrm{P}<0.0001)$ between the two assessed dosages. The dosage of $1300 \mathrm{IJ} / \mathrm{cm}^{2}$ produced the highest mortality rate, at $82.3 \%$ (Table 5). Based on these results and taking into consideration that it is a nematode isolated from the soil at an oil palm plantation, Heterorhabditis sp. (CPHsp1301) was selected for assessment in field conditions in three dosages. There are some differences known in terms of survival, pathogenicity and host range between indigenous and non-indigenous nematodes species. Indigenous species of nematodes may be more successful in biocontrol because of compatibility to native habitats $[14,32]$.

Table 5. Mortality (\%) of stage IV nymphs of Haplaxius crudus caused by different dosages of Steinernema sp.1 and Heterorhabditis sp. (CPHsp1301) under mesh house conditions.

\begin{tabular}{lll}
\hline \multirow{2}{*}{ Dosage } & \multicolumn{2}{l}{ \% mortality nymphs of H. crudus } \\
\cline { 2 - 3 } & Steinernema sp. 1 & Heterorhabditis $\mathbf{s p .}$ (CPHsp1301) \\
\hline $100 \mathrm{IJ} / \mathrm{cm}^{2}$ & $42.1 \mathrm{~b}^{*}$ & $47.0 \mathrm{~b}$ \\
$500 \mathrm{IJ} / \mathrm{cm}^{2}$ & $73.5 \mathrm{a}$ & $75.4 \mathrm{a}$ \\
$1300 \mathrm{IJ} / \mathrm{cm}^{2}$ & $75.4 \mathrm{a}$ & $82.3 \mathrm{a}$ \\
Control & $4.9 \mathrm{c}$ & $0 \mathrm{c}$ \\
\hline
\end{tabular}

*Data in the same column followed by the same letter are not significantly different according to the Duncan test $(\mathrm{P}<0.05)$.

\subsection{Field Assessment}

The mortality of nymphs of $H$. crudus produced by Heterorhabditis sp. (CPHsp1301) with the evaluation of three dosages under simulated field conditions displayed statistically significant differences $(\mathrm{F}=19.6$; df $=3$; $\mathrm{P}<$ 0.0001 ) among the assessed dosages, of which the dosage of $1300 \mathrm{IJ} / \mathrm{cm}^{2}$ produced the greatest mortality rate $(78.4 \%)$ (Table 6).

It should be noted that increasing the dosage from 1000 to $1300 \mathrm{IJ} / \mathrm{cm}^{2}$ did not significantly increase the mortality rate, which indicates that after reaching a certain threshold an 
increase in nematodes does not imply a higher mortality rate $[33,34]$. It should also be pointed out that the dosages assessed in this study are high, but consistent with other experiments that recommend high dosages to control insects, such as those performed in reference [35] using a dosage of $1.2 \times 10^{10} \mathrm{IJ} / \mathrm{ha}$ of $S$. riobrave to control Diaprepes abbreviates L. (Coleoptera: Curculionidae), producing mortality rates of over $90 \%$, and those performed in reference [36] using a dosage of $1.5 \times 10^{11} \mathrm{IJ} /$ ha of Heterorhabditis $\mathrm{sp}$. to control the spittle $A$. varia, producing a mortality rate of $76 \%$.

Table 6. Mortality (\%) of nymphs of Haplaxius crudus caused by different dosages of the entomopathogenic nematode Heterorhabditis sp. (CPHsp1301) under simulated field conditions.

\begin{tabular}{ll}
\hline $\begin{array}{l}\text { Dosage of Heterorhabditis sp. } \\
\text { (CPHsp1301) }\end{array}$ & $\begin{array}{l}\text { \% mortality nymphs of } \boldsymbol{H} . \\
\text { crudus }\end{array}$ \\
\hline $500 \mathrm{IJ} / \mathrm{cm}^{2}$ & $58.8 \mathrm{a}$ \\
$1000 \mathrm{IJ} / \mathrm{cm}^{2}$ & $71.5 \mathrm{~b}$ \\
$1300 \mathrm{IJ} / \mathrm{cm}^{2}$ & $78.4 \mathrm{~b}$ \\
Control & $25.5 \mathrm{c}$ \\
\hline
\end{tabular}

*Data in the same column followed by the same letter are not significantly different according to the Duncan test $(\mathrm{P}<0.05)$.

\section{Conclusions}

Although this is the first report that studies the efficacy of entomopathogenic nematodes against $H$. crudus, the results of this study demonstrate the potential of Heterorhabditis sp. (CPHsp1301) to reduce $H$. crudus nymphs populations, reproduce inside the insect, to emerge and to produce secondary infections. Further research is needed, to validate these results to control $H$. crudus under commercial oil palm plantations, so this strategy can be incorporated in an integrated pest management program against this insect.

\section{Acknowledgements}

The authors express their gratitude to Guaicaramo S. A., to facilitate the oil palm plantation to conduct this research. Also to Cenipalma and Oil Palm Fund for supporting this research.

\section{References}

[1] TORRES, E.; TOVAR, J. 2004. Estudio epidemiológico de la enfermedad marchitez letal de la palma de aceite en plantaciones de Villanueva, Casanare. Palmas (Colombia) 25 (2): $210-211$.

[2] FEDERACIÓN NACIONAL DE CULTIVADORES DE PALMA DE ACEITE (FEDEPALMA). Informe de gestión 2017 (Colombia). 298 p.

[3] ARANGO, M.; OSPINA, C.; SIERRA, J.; MARTÍNEZ, G. 2011. Myndus crudus: vector del agente causante de la marchitez letal en palma de aceite en Colombia. Palmas (Colombia) 32 (2): 13-25.

[4] HOWARD, F.; GALLO, S. 2006. El cixíido americano de las palmas, Myndus crudus Van Duzee (Insecta: Hemiptera: Auchenorrhyncha: Fulgoroidea: Cixiidae). University of Florida- IFAS Extensión. 10 p.

[5] SIERRA, M. L. J.; BUSTILlO, P. A. E.; ROSERO, E. G. A.; GUTERREZ, H. J.; MARTINEZ, P. J. A. 2014. Plantas hospederas del vector de la Marchitez letal, Haplaxius crudus, en plantaciones de palma de aceite. Ceniavances (Colombia) 177: $1-4$.

[6] HOWARD, F. W. 2015. American palm cixiid - Myndus crudus Van Duzee. Featured Creatures. University of Florida. http://entnemdept.ufl.edu/creatures/orn/palms/palm_cixiid.htm

[7] BUSTILlo, P. A. E.; ARANGO, M. 2016. Las mejores prácticas para detener el avance de la Marchitez letal (ML) en plantaciones de palma de aceite en Colombia. Palmas 37 (4): 75-90.

[8] ARANGO, M.; SIERRA, J.; ALDANA, R; MARTÍNEZ, G. 2011. Efecto de la aplicación de insecticidas y herbicidas en el desarrollo de marchitez letal (ML) de la palma de aceite en el Bajo Upia, Casanare, Colombia. Palmas (Colombia) 32 (1): 11-24.

[9] HOWARD, F. W.; EDWARDS, G. B. 1984. Web- building spiders on coconut palms and their prey. Folia entomológica Mexicana 62: 81-87.

[10] VILlANUEVA, B. J.; PIÑA, R. J. CARRILlO, R. H. 1987. Avances sobre el control y la investigación del amarillamiento letal del cocotero en México. Folleto técnico N ${ }^{\circ} 1$. SARH. 19 p.

[11] CARRILLO, R. H.; RAMIREZ, P. J. 1994. Investigación y algunas estrategias de manejo sobre el Amarillamiento Letal del Cocotero en la Península de Yucatán. Folleto técnico. Nov 1994. Centro de Investigación Regional del Sureste. México. $25 \mathrm{p}$.

[12] BOUCIAS, D. G.; MEYER, M. J.; POPOONSAK, S.; BREAUX, S. E. 2007. The genus Hirsutella: A polyphyletic group of fungal pathogens infecting mites and insects. pp. 134. In: Ekesi, S.; Maniania, N. K. (Eds). Use of Entomopathogenic Fungi in Biological Pest Management. Research Signpost. India. 321 p.

[13] ARANGO, M.; OSPINA, C.; SIERRA, J.; MARTÍNEZ, G. 2012. Manejo de la marchitez letal en palma de aceite en zonas de alta incidencia. Palmas (Colombia) 33 (4): 29-40.

[14] LACEY, L. A, GEORGIS, R. 2012. Entomopathogenic nematodes for control of insect pests above and below ground with comments on commercial production. Journal of Nematology 44 (2): 218-225.

[15] GREWAL, P. S.; EHLERS, R. U.; SHAPIRO-ILAN, D. I. 2005. Nematodes as Biocontrol Agents. CABI Publishing, Wallingford, UK. 505 p.

[16] KAYA, H. K. 1990. Soil ecology. pp. 93-115. In: Gaugler R.; Kaya, H. K. (Eds.). Entomopathogenic nematodes in biological control. CRC Press. Boca Raton, Florida. 365 p.

[17] GUO, W.; YAN, X.; ZHAO, G.; HAN, R. 2016. Increased efficacy of entomopathogenic nematode-insecticide combinations against Holotrichia oblita (Coleoptera: Scarabaeidae). Journal of Economic Entomology. 110 (1): 4151. 
[18] LEWIS, E. E.; CLARKE, D. J. 2012. Nematode parasites and entomopathogens. pp. 395-424. In: Vega, F. E.; Kaya, H. K (Eds). Insect pathology, 2nd edn. Elsevier, London.

[19] GLAZER, I. 1996. Survival mechanisms of entomopathogenic nematodes. Biocontrol Science and Technology 6 (3): 373378.

[20] KAYA, H. K.; KOPPENHÖFER, A. M. 1996. Effects of microbial and other antagonistic organism and competition on entomopathogenic nematodes. Biocontrol Science and Technology 6: 357-371.

[21] AKHURST, R.; SMITH, K. 2002. Regulation and Safety. p. 311- 326. In: Gaugler, R. (Ed.). Entomopathogenic nematology. CAB International, Wallingford. $399 \mathrm{p}$.

[22] REALPE, A. F. J.; BUSTillo, P. A. E.; LÓPEZ, N. J. C. 2007. Optimización de la cría de Galleria mellonella (L.) para la producción de nematodos entomopatógenos parásitos de la broca del café. Revista Cenicafé (Colombia) 58 (2): 142-157.

[23] LÓPEZ, N. J. C. 2008. Nematodos para el control de insectos plagas. pp. 150-183. En: Bustillo, P. A. E. (Ed.). Los insectos y su manejo en la caficultura colombiana. FNC - Cenicafé, Chinchiná (Colombia). Editorial Blancolor Ltda., Manizales, $466 \mathrm{p}$.

[24] KAYA, H. K.; STOCK, S. P. 1997. Techniques in insect nematology. pp. 281-324. In: Lacey, L. A. (Ed.). Manual of techniques in insect pathology. Biological techniques series. Academic Press. San Diego, USA. 409 p.

[25] GAUGLER, R.; LEWIS, E.; STUART, R. J. 1997. Ecology in the service of biological control: the case of entomopathogenic nematodes. Oecologia 109: 483-489.

[26] ROSERO, G. M.; BUSTILlO, P. A. E.; LOPEZ, N. J. C.; CASTRO, V. U.; GOMEZ, L. E. D. 2012. Eficacia de entomonematodos para controlar estados de Aeneolamia varia (Hemiptera: Cercopidae) bajo condiciones de invernadero. Revista Colombiana de Entomología 38 (2): 266-273.

[27] MA, J.; CHEN, S.; MOENS, M.; HAN, R.; CLERCQ. 2013. Efficacy of entomopathogenic nematodes (Rhabditida: Steinernematidae and Heterorhabditidae) against the chive gnat, Bradysia odoriphaga. Journal of Pest Science 86 (3): 551-561.

[28] EBSSA, L.; KOPPENHÖFER, A. M. 2012. Entomopathogenic nematodes for the management of Agrotis ipsilon: effect of instar, nematode species and nematode production method. Pest Management Science 68 (6): 947957.

[29] GRIFFIN, C. T. 2015. Behaviour and Population Dynamics of Entomopathogenic Nematodes Following Application. pp 5795. In: Campos Herrera R (ed). Nematode pathogenesis of insects and other pests - ecology and applied technologies for sustainable plant and crop protection, 1st edn. Springer, Berlin.

[30] POWER, K. T.; AN, R.; GREWAL, P. S. 2009. Effectiveness of Heterorhabditis bacteriophora strain GPS11 applications targeted against different instars of the Japanese beetle Popillia japonica. Biological Control 48: 232-236.

[31] PATIL, J.; RANGASAMY, V. 2018. Field evaluation of the entomopathogenic nematodes against the white grub, Leucopholis lepidophora Blanchard (Coleoptera: Scarabaeidae). Egyptian Journal of Biological Pest Control 28: 41 .

[32] GOUDARZI, M.; MOOSAVI, M. R.; ASADI, R. 2015. Effects of entomopathogenic nematodes, Heterorhabditis bacteriophora (Poinar) and Steinernema carpocapsae (Weiser), in biological control of Agrotis segetum (Denis \& Schiffermuller) (Lepidoptera: Noctuidae). Türkiye Entomoloji Derneği 39 (3): 239-250.

[33] HÜBNER, A.; ENGLERT, C.; HERZ, A. 2017. Effect of entomopathogenic nematodes on different developmental stages of Drosophila suzukii in and outside fruits. Biological Control 62: 669-680.

[34] LANGFORD, E. A.; NIELSEN, U. N, JOHNSON, S. N.; RIEGLER, M. 2014. Susceptibility of Queensland fruit fly, Bactrocera tryoni (Froggatt) (Diptera: Tephritidae), to entomopathogenic nematodes. Biological Control 69: 34-39.

[35] McCOY, C. W.; STUART, R. J.; DUNCAN, L. W.; NGUYEN, K. 2002. Field efficacy of two commercial preparations of entomopathogenic nematodes against larvae of Diaprepes abbreviates (Coleoptera: Curculionidae) in alfisol type soil. Florida Entomologist. 85 (4): 537-544.

[36] MORENO, S. C. A.; BUSTILlO, P. A. E.; LOPEZ, N. J. C.; CASTRO, V. U.; RAMIREZ, S. G. D. 2012. Virulencia de nematodos entomopatógenos para el control del salivazo Aeneolamia varia (Hemiptera: Cercopidae) en caña de azúcar. Revista Colombiana de Entomología 38 (2): 260-265. 